\title{
Topochemical analyses of furfuryl alcohol- modified radiata pine (Pinus radiata) by UMSP, light microscopy and SEM
}

DOI 10.1515/hf-2016-0219

Received November 25, 2016; accepted May 11, 2017; previously published online June 16, 2017

\begin{abstract}
Furfurylation is one of the wood modification techniques via catalytic polymerization of the monomeric furfuryl alcohol (FA) in the impregnated cell wall. Little is known about the topochemistry of this process. Brown rot degradation begins with lignin modification and therefore, the reactions between FA and lignin was one focus of this research. Furfurylated radiata pine (Pinus radiata) with three different weight percent gains (WPGs of 57\%, $60 \%$ and $70 \%$ ) after FA uptake was observed by cellular ultraviolet microspectrophotometry (UMSP) to analyze chemical alterations of the individual cell wall layers. Moreover, light microscopy (LM) and scanning electron microscopy (SEM) analyses were performed. The ultraviolet (UV) absorbance of the modified samples increased significantly compared to the untreated controls, indicating a strong polymerization of the aromatic compounds. Highest UV absorbances were found in areas with the highest lignin concentration. The UMSP images of individual cell wall layers support the hypothesis concerning condensation reactions between lignin and FA.
\end{abstract}

Keywords: brown rot, furfurylation, light microscopy (LM), lignin modification, scanning electron microscopy (SEM), ultraviolet microspectrophotometry (UMSP), wood modification

\footnotetext{
*Corresponding author: Gabriele Ehmcke, Chair of Wood Science, Technical University of Munich, Winzererstraße 45, D-80797 München, Germany, Phone: +49 892180 6431, e-mail: ehmcke@hfm.tum.de

Annica Pilgård: Chair of Wood Science, Technical University of Munich, Winzererstraße 45, D-80797 München, Germany; and RISE Research Institutes of Sweden AB, Box 857, SE-501 15 Borås, Sweden Gerald Koch: Thünen Institute of Wood Research, Leuschnerstr. 91, D-21031 Hamburg, Germany

Klaus Richter: Chair of Wood Science, Technical University of Munich, Winzererstraße 45, D-80797 München, Germany
}

\section{Introduction}

Brown rot basidiomycetes cause the most destructive type of wood decay, even before any mass loss (ML) of the wood is detectable (Schultze-Dewitz 1966; Bariska et al. 1983; Winandy and Morrell 1993). Cellulose and hemicelluloses are mainly metabolized, leaving a modified lignin behind (Danninger et al. 1980; Eriksson 1990; Goodell 2003). Lignin maintains its macromolecular nature throughout the brown rot decay (Kirk 1975; Niemenmaa et al. 2008; Yelle et al. 2008), but its structure is modified substantially by hydroxyl radicals produced by the fungi (Yelle et al. 2008, 2011; Arantes et al. 2009, 2011; Martínez et al. 2011). The lignin modification begins in the outermost part of the secondary cell wall (S2) and the compound middle lamella (CML) (Fackler et al. 2010; Rehbein and Koch 2011).

Wood preservation based on technologies with low environmental impact are mandatory today. Different approaches are known in this regard, for instance, modifications with melamine formaldehyde (Stamm 1964), with acetic anhydride (Rowell et al. 1994), or thermal modification (Militz 2002), the effects of which are based on chemical, biological and physical interactions, resulting in increased durability and dimensional stability (Hill 2006; Ringman et al. 2014). Another promising approach is the furfurylation process. Furfuryl alcohol (FA) is obtained from renewable resources of agricultural crop waste (corn or sugar cane production) consisting of pentosans, which are easily hydrolyzed, and the pentoses obtained are dehydrated to furfural (F) (Hill 2006; Uppal et al. 2008; Moghaddam et al. 2016), which is then converted to FA. $\mathrm{F}$ and FA are by far the most important furan derivates (Gandini and Lacerda 2015), which can be polymerized by several organic and mineral acids, such as by Lewis acids (Lande et al. 2004a). Ünver and Öktem (2013) investigated controlled cationic polymerization of FA, visualized by the UV bands at $\lambda_{228 \mathrm{~nm}}$ and $\lambda_{286 \mathrm{~nm}}$.

Furfurylation begins with FA impregnation of wood followed by in situ polymerization, which leads to a permanent swelling of the cell wall (Goldstein 1955, 1960; Stamm 1977; Schneider 1995; Bryne et al. 2010). In the last decade, FA impregnation was, for example, applied to 
improve plasticization and fixation during the densification of wood (Pfriem et al. 2012), and new catalysts were developed (Li et al. 2015; Sejati et al. 2017). Not all the details of the furfurylation process are well understood. The FA solution enters the cell wall to some extent but also fills the cell lumens completely or partially (Schneider et al. 2000). Depending on wood species and FA concentration, the curing temperature ranges from $45^{\circ} \mathrm{C}$ to $140^{\circ} \mathrm{C}$ (Westin 2003). Furfurylated wood $\left(\mathrm{W}_{\mathrm{FA}}\right)$ has better durability against biodegradation (Lande et al. 2004c; Esteves et al. 2011; Gascon-Garrido et al. 2013; Li et al. 2015; Sejati et al. 2017) and has a low environmental impact (van Eetvelde 1998; Lande et al. 2004a,b,c; Pilgård et al. 2010a, 2010b). Furfurylated softwoods and hardwoods are available on the market with the equivalent quality to woods protected by copper, chromium and arsenic (CCA) solutions. $\mathrm{W}_{\mathrm{FA}}$ is darker than native wood and has an aesthetic appeal similar to that of natural durable (and dark) tropical timbers like teak, ipé or azobé. $\mathrm{W}_{\mathrm{FA}}$ fulfills the requirements for hazard classes 3 and 4 applications according to EN 335. Furfurylated southern yellow pine and radiata pine are admitted as "proven" for window frames on the German market (VFF-Merkblatt HO.06-4 2016). Previous studies by infrared (Venås and Rinnan 2008) and fluorescence microscopy (Thygesen et al. 2010) on $\mathrm{W}_{\mathrm{FA}}$ have shown that FA polymerization takes place within the wood tissue. Higher fluorescence occurs in lignin-rich parts, mainly in the cell wall corner regions (CC) and the CML (Thygesen et al. 2010). Nuclear magnetic resonance (NMR) spectra of early stages of FA polymerization demonstrated that lignin model compounds form covalent bonds in a liquid-phase system with the FA polymer (Nordstierna et al. 2008). Chemical bonds between the FA polymer and wood tissue, however, have not yet been proven.

To learn more about furfurylation, ultraviolet microspectrophotometry (UMSP) was applied in the present study. UMSP is an established analytical technique which enables the direct imaging of lignin distribution and lignin modification in the course of biodegradation and technological delignification within individual cell wall layers in situ (Fergus et al. 1969; Scott et al. 1969; Saka et al. 1982; Fukazawa 1992; Koch and Kleist 2001; Koch et al. 2003a; Koch et al. 2003b; Koch and Grünwald 2004; Rehbein and Koch 2011; Koch and Schmitt 2013; Aguayo et al. 2014; Kojima et al. 2014; Bianchi et al. 2016; Ehmcke et al. 2016). The $\pi$ electron-rich lignin shows UV maxima at around $\lambda_{212 \mathrm{~nm}}$ and $\lambda_{280 \mathrm{~nm}}$ (Scott et al. 1969; Goldschmid 1971; Fukazawa 1992). Softwood lignin is mainly composed of guaiacylpropane moieties with an absorbance maximum $\left(\mathrm{A}_{\max }\right)$ at around $\lambda_{280 \mathrm{~nm}}$ (Musha and Goring 1975; Takabe 1992). The $\mathrm{UV}^{-\mathrm{A}_{\max }}$ data are lower in lignins with higher syringpropan unit participation, seen on the increasing $\mathrm{OCH}_{3} / \mathrm{C}_{9}$ ratios (Musha and Goring 1975; Fujii et al. 1987). Modified timbers, such as heat-treated and N-methylol melamine-modified hardwoods (Kielmann et al. 2013; Mahnert et al. 2013; Sint et al. 2013), hydrothermal-modified wood (Andersons et al. 2016) and degraded furfurylated softwood (Ehmcke et al. 2016), were also studied by UMSP.

The aim of the present study was to investigate FAmodified radiata pine (Pinus radiata) by the UMSP method to search for indications of lignin modification via chemical bonds with FA.

\section{Materials and methods}

Radiata pine ( $P$. radiata) sapwood boards were industrially furfurylated under different process conditions and distributed to project partners of an ongoing research project (Research council of Norway project 219294/O30). The furfurylation processes are based on a full-cell impregnation with different FA solutions, buffer agents and catalysts followed by steam curing and kiln drying. Water-based [process A, a weight percent gain (WPG) of 60\%] and alcohol solutions (process B, 70\% WPG) were applied, both containing FA and standard catalysts. Process $\mathrm{C}$ was performed with an experimental mix of a water-based solution and an alternative catalyst leading to a WPG of $57 \%$. The wood from process A is a commercial product and available on the market. Each modified board in this project was matched by an untreated board $\left(\mathrm{W}_{\text {untr }}\right)$.

Sample preparation for UMSP: Small blocks of $\mathrm{W}_{\mathrm{FA}} 1 \mathrm{~mm} \times 1 \mathrm{~mm} \times$ $5 \mathrm{~mm}(\mathrm{R} \times \mathrm{T} \times \mathrm{L})$ were prepared for each treatment type $\left(\mathrm{W}_{\mathrm{FA}, \mathrm{A}}, \mathrm{W}_{\mathrm{FA}, \mathrm{B}}\right.$ and $\left.\mathrm{W}_{\mathrm{FA}, \mathrm{C}}\right)$ and for $\mathrm{W}_{\text {untr. }}$. Selected wood blocks were dehydrated in a graded series of ethanol and then embedded in Spurr's (1969) epoxy resin (Electron Microscopy Sciences, Hatfield, PA, USA) under mild vacuum conditions. The polymerization process was catalyzed by thermal curing at $70^{\circ} \mathrm{C}$ for $12 \mathrm{~h}$. The embedded specimens were trimmed with a razor blade (Plano $\mathrm{GmbH}$, Wetzlar, Germany) to provide an area of approximately $0.5 \mathrm{~mm}^{2}$ and sectioned with a rotary microtome (Leica, RM2265, Leica Mikrosysteme Vertrieb GmbH Wetzlar, Germany) equipped with a diamond knife (DiATOME histo, $4.0 \mathrm{~mm}, 45^{\circ}$, Diatome AG, Biel, Switzerland). The semi-thin sections $(1 \mu \mathrm{m})$ were transferred to quartz microscopic slides (Plano $\mathrm{GmbH}$, Wetzlar, Germany) and thermally fixed. The sections were immersed in a drop of non-UV-absorbing glycerine (glycerine/water mixture $\mathrm{n}_{\mathrm{D}}=1.46$ ) and covered with a quartz cover slip. As reference, unmodified radiata pine sapwood specimens were also prepared, following the same embedding process.

In addition, small cubes $\left(1 \mathrm{~cm}^{3}\right)$ of $\mathrm{W}_{\mathrm{untr}}$ and $\mathrm{W}_{\mathrm{FA}}$ were prepared for light microscopy (LM) and scanning electron microscopy (SEM) analyses. For conventional LM, the cubes were sectioned with a sliding microtome (Leica SM 2000 R, Leica Mikrosysteme Vertrieb GmbH Wetzlar, Germany) and sections of the three anatomical directions (transverse, radial and tangential) were mounted on microscopic slides and embedded in Euparal (Carl Roth, Carl Roth GmbH + Co. KG, Karlsruhe, Germany). For SEM analysis, specimens were boiled in water and then manually cut with a thin razorblade to obtain a plain surface perpendicular to the axial direction. The specimens were stored overnight 
under vacuum and then sputter-coated by a coating unit (International Scientific Instruments Co, New Delhi, India) with a 10-15-nm gold film.

Cellular UMSP: The ultrathin sections were placed in a Zeiss UMSP 80 (Carl Zeiss AG, Oberkochen, Germany) equipped with a scanning stage. The principle of the UMSP investigation is based on the typical UV absorbance of lignin in the range of $\lambda_{270-280 \mathrm{~nm}}$ (Musha and Goring 1975). For scanning, a defined wavelength of $\lambda_{280 \mathrm{~nm}}$ (the $A_{\max }$ of softwood lignin) was selected. The scan program Automatic Photometric Analysis of Microscopic Objects by Scanning (APAMOS, Carl Zeiss AG, Oberkochen, Germany) digitizes square fields of a local geometrical resolution of $0.25 \mu \mathrm{m} \times 0.25 \mu \mathrm{m}$ and a photometrical resolution of 4096 grayscale levels. To visualize the absorbance intensities, the grayscale levels were converted into 14 basic colors as described in detail by Koch and Kleist (2001). The scans can be depicted as two-dimensional (2D) or three-dimensional (3D) image profiles, and a statistical data evaluation results in a semi-quantitative lignin distribution. For control purposes, the lignin distribution within individual cell types and cell wall layers of three $\mathrm{W}_{\text {untr }}$ specimens were scanned.

In addition, the specimens were also subjected to photometric point measurements with a spot size of $1 \mu \mathrm{m}^{2}$. The UV spectra of individual cell wall layers were recorded in the range between $\lambda_{250 \mathrm{~nm}}$ and $\lambda_{420 \mathrm{~nm}}$ and statistically evaluated. A TIDAS MSP 800 microscope spectrometer (J\&M Analytik AG, Esslingen, Germany) equipped with TIDAS-DAQ software was available. The spectral characteristics of 15-20 point measurements of individual cell wall layers and FApolymerized deposits in the lumen were evaluated.

LM and SEM: To localize FA-impregnated cell elements, selected samples were analyzed by conventional LM (Axiophot, Carl Zeiss AG, Oberkochen, Germany) equipped with a digital camera (AxioCam, Carl Zeiss AG, Oberkochen, Germany) combined with AxioVision software (Carl Zeiss AG, Oberkochen, Germany). The SEM was equipped with a tungsten cathode (EVO 40, 10-12 kV, Carl Zeiss AG, Oberkochen, Germany).

\section{Results and discussion}

Transverse sections of $\mathrm{W}_{\text {untr }}$ and $\mathrm{W}_{\mathrm{FA}}$ from the FA modification processes were observed by cellular UV microscopy at $\lambda_{280 \mathrm{~nm}}$. Preliminary tests showed that the standard thresholds for the UMSP analyses of untreated wood tissue (min $10 \%$ and $\max 80 \%$ ) were not suitable to evaluate $\mathrm{W}_{\mathrm{FA}}$ due to the high absorbance intensities (Ehmcke et al. 2016). To obtain a comparable evaluation and image generation, the thresholds were therefore individually adapted to a minimum of $1.0 \%$ and a maximum of $67.5 \%$ for all investigated specimens.

a
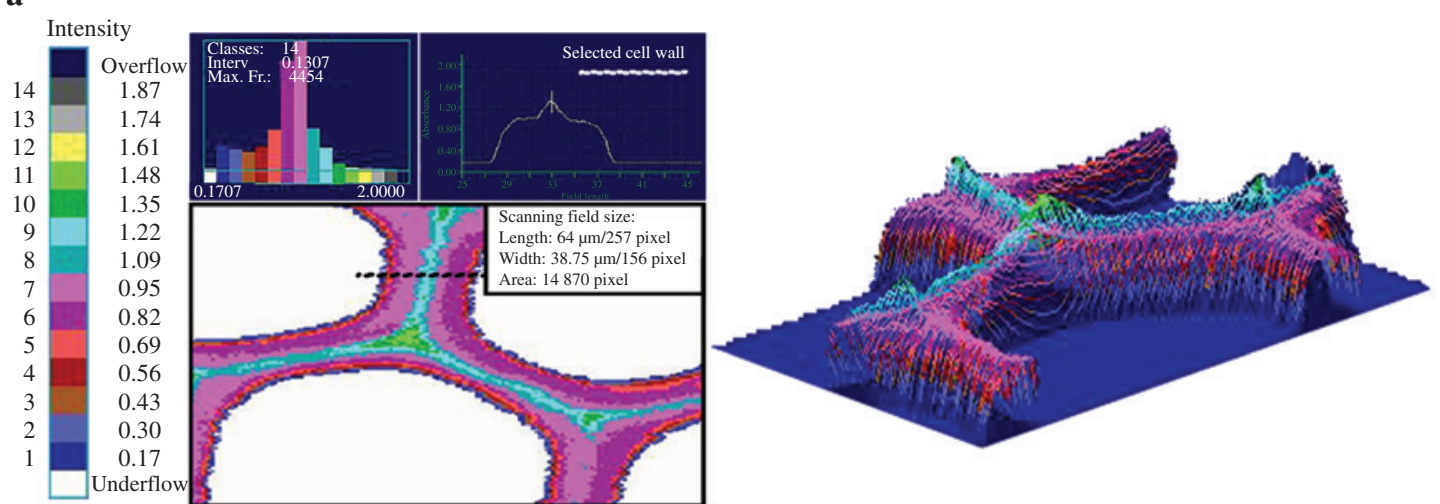

b Intensity
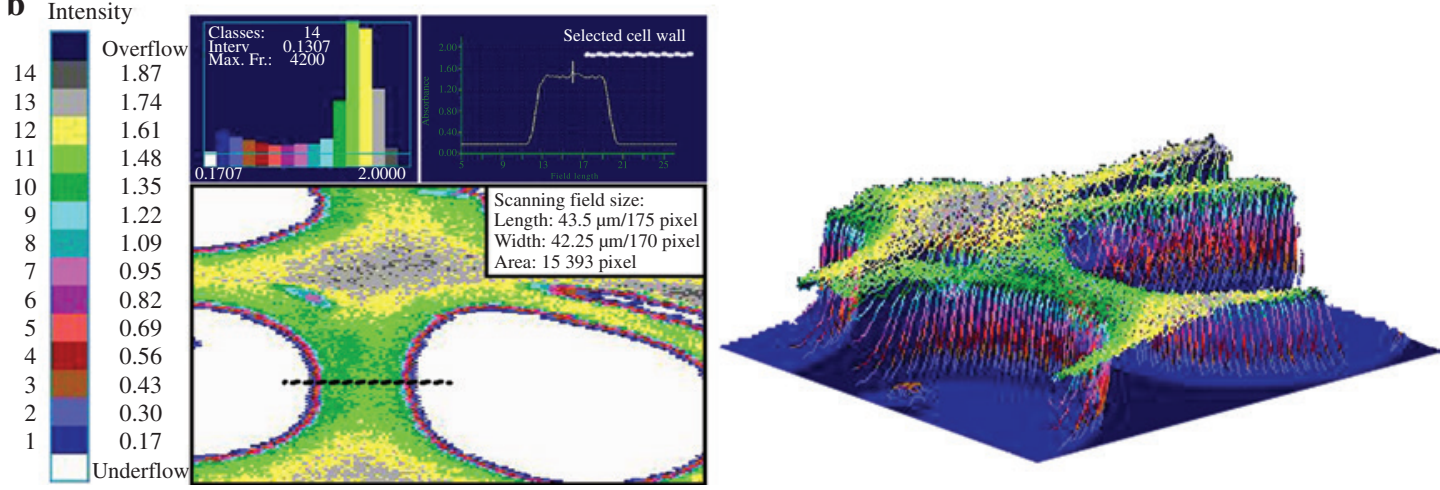

Figure 1: UV microscopic scanning profiles of untreated (a) and furfurylated (b) radiata pine (process A, 60\% WPG).

The data are statistically evaluated from their corresponding histograms. The colored pixels mark the absorbance intensity at $\lambda_{280 \mathrm{~nm}}$. A selective line scan of an individual cell wall region intuitively visualizes the local lignin concentration and chemical cell wall modification. 


\section{UV microscopic scanning profiles}

In Figure 1, representative UV microscopic scanning profiles of $\mathrm{W}_{\text {untr }}$ and $\mathrm{W}_{\mathrm{FA}, \mathrm{A}}(60 \% \mathrm{WPG}$, commercial product) are presented. The colored pixels mark the absorbance intensities at $\lambda_{280 \mathrm{~nm}}$. The data of each UV profile are statistically evaluated from its corresponding histogram. The high resolution $\left(0.25 \mu \mathrm{m}^{2}\right.$ per pixel) enables a detailed differentiation of the UV absorbance within the individual cell wall layers (Koch et al. 2003a). In addition to the standard 2D UV micrograph, a selective line scan of an individual cell wall region intuitively visualizes the local lignin concentration and the chemical cell wall modification. For spatial illustration, the scanning area is also presented as a 3D image profile.

A representative profile of natural lignin distribution in cell walls of $\mathrm{W}_{\text {untr }}$ is presented in Figure 1a. The highest absorbances occur in the area of the CML and the CC as previously described for $\mathrm{W}_{\text {untr }}$ (Koch and Kleist 2001; Koch and Grünwald 2004) and also for thermally (Mahnert et al. 2013) and hydrothermally modified wood (Andersons et al. 2016). For the $W_{\text {untr }}$ tissue, the following UV absorption data $\left(\mathrm{A}_{280 \mathrm{~nm}}\right)$ are typical: 1.22 for the CML, 1.48 for the CC and lower, slightly varying values for the S2 layer (0.690.95). The fluctuating values for the $S 2$ layer were already described by Takabe (2002). The line scan of a double cell wall in the radial direction and the corresponding 3D image illustrates the high absorbance intensities of the CML as a pronounced peak and a highly absorbing band.

For comparison, the UV scanning profiles of $\mathrm{W}_{\text {untr }}$ and $\mathrm{W}_{\mathrm{FA}, \mathrm{A}}(60 \% \mathrm{WPG})$ are presented in Figure 1. The profiles (Figure 1b) show significantly higher absorbances of the entire cell wall compared to $\mathrm{W}_{\text {untr }}$. With regard to the typical lignin distribution, both UV micrographs of $\mathrm{W}_{\text {untr }}$ and $\mathrm{W}_{\mathrm{FA}}$ reveal a similar spectral behavior, where the absorbance intensities are increasing from the S3 layer towards the area of the CML and the CC. For $\mathrm{W}_{\mathrm{FA}}$, a clear shift is visible to green-, yellow-, and gray-colored pixels, representing higher UV intensities in the range of 1.22-1.74 $\left(\mathrm{A}_{280 \mathrm{~nm}}\right)$, as it was already documented by Ehmcke et al. (2016). With reference to fluorescence studies (Thygesen et al. 2010), the highest amount of polymerized FA was detected in the lignin-rich areas. The line scan in Figure $1 \mathrm{~b}$ visualizes a distinct increase of the absorbance values from the outer cell wall towards the CML. On the other hand, the CML evinces a less-pronounced peak compared to $\mathrm{W}_{\text {untr }}$ in Figure 1a. The CML in Figure $1 \mathrm{~b}$ is associated with a broad plateau of high UV intensities representing the S2 layer $\left(\mathrm{A}_{280 \mathrm{~nm}} 1.22-1.35\right)$, which indicates an intensive modification of the cell wall.

$\mathrm{W}_{\mathrm{FA}, \mathrm{B}}(70 \% \mathrm{WPG})$ and $\mathrm{W}_{\mathrm{FA}, \mathrm{C}}(57 \% \mathrm{WPG})$ are presented in Figures 2 and 3. The cell wall layers of $\mathrm{W}_{\mathrm{FA}, \mathrm{B}}$ (Figure 2) reveal relatively homogenous absorbance intensities in the green color range $\left(\mathrm{A}_{280 \mathrm{~nm}} 1.22-1.35\right)$. The $\mathrm{CC}$ and $\mathrm{CML}$ are somewhat more pronounced and characterized by rare yellow pixels $\left(A_{280 \mathrm{~nm}}\right.$ 1.48). Figure 3 shows lower intensities with bluish-green colors for $\mathrm{W}_{\mathrm{FA}, \mathrm{C}}$. The cell wall layers of $\mathrm{W}_{\mathrm{FA}, \mathrm{C}}$ show increasing intensities beginning with the cell lumen $\left(\mathrm{A}_{280 \mathrm{~nm}} 0.17-0.56\right)$ to $\mathrm{S} 2\left(\mathrm{~A}_{280 \mathrm{~nm}} 1.09-1.22\right)$, to the CML and the $\mathrm{CC}\left(\mathrm{A}_{280 \mathrm{~nm}} 1.35-1.61\right)$, where the absorbance intensities culminate. Compared to $\mathrm{W}_{\text {untr }}$ (Figure 1a) and all other treated materials (Figures $1 \mathrm{~b}, 2$ and 3), the wood tissue of $\mathrm{W}_{\mathrm{FA}, \mathrm{A}}$ (Figure 1b) shows the highest absorbances with a clear shift to green, yellow and gray pixels $\left(\mathrm{A}_{280 \mathrm{~nm}} 1.22-1.74\right)$.

The mean UV absorbances did not increase proportionally to the loadings (i.e. to the WPGs) of the analyzed samples (Table 1). The highest loading was generated by process B with 70\% WPG, representing the lowest $A_{280 \mathrm{~nm}}$ with 1.07 , compared to process $A$ with $A_{280 \mathrm{~nm}} 1.16$ and $C$ with $A_{280 \mathrm{~nm}} 1.09$, but these differences are not significant. The slight deviations could be explained by differences in the anatomical structure and the high resolution of the individual measuring fields. In general, the individual parameters of the FA modification (in terms of catalyst concentration,
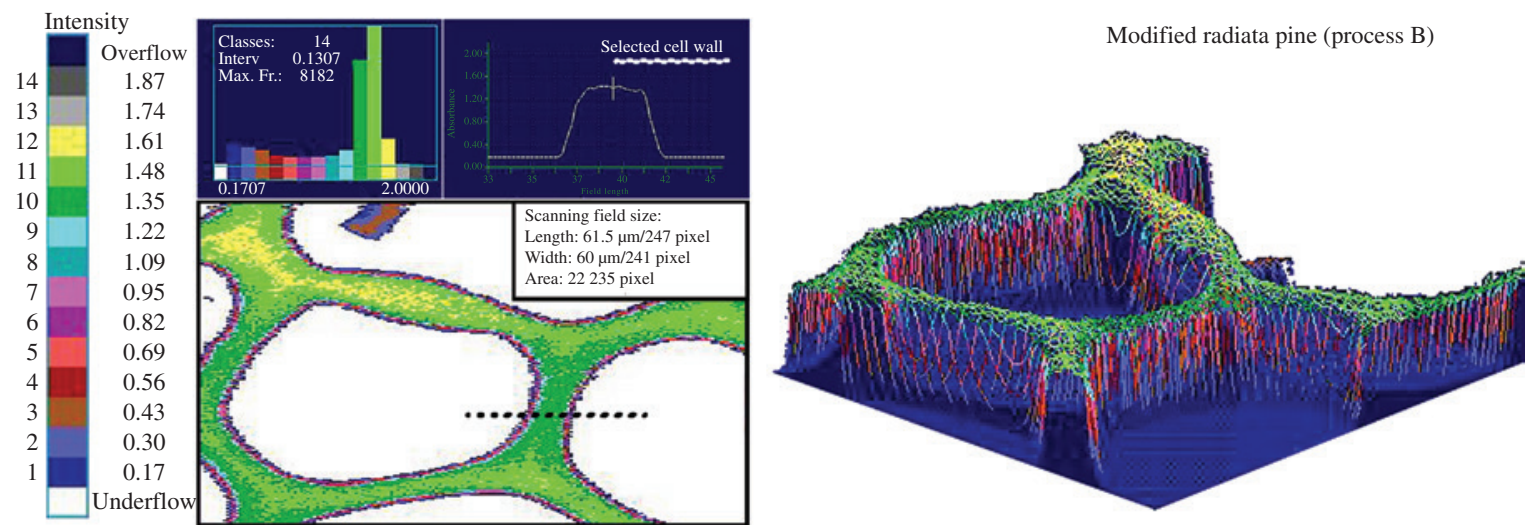

Figure 2: UV microscopic scanning profiles of furfurylated radiata pine (process $B, 70 \%$ WPG). 


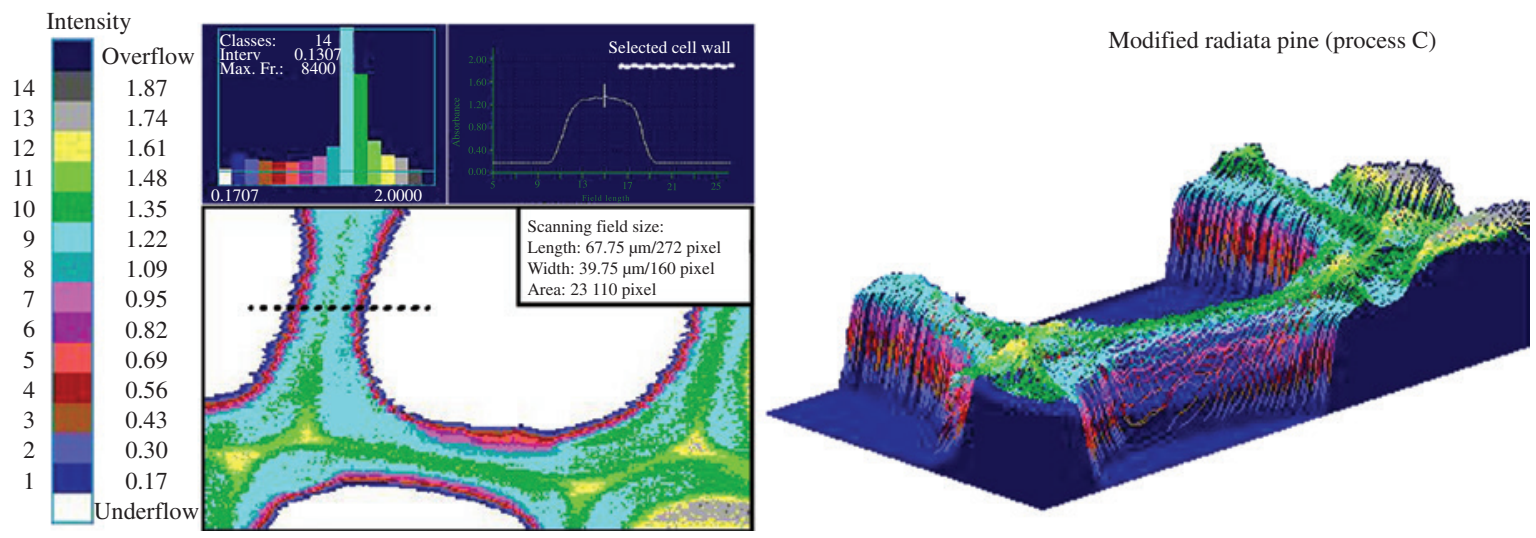

Figure 3: UV microscopic scanning profiles of furfurylated radiata pine (process C, 57\% WPG).

Table 1: Mean UV absorbance $\left(A_{280 n m}\right)$ of untreated and modified radiata pine and maximum UV absorbance values $\left(A_{\max }\right)$ of polymerized FA deposits (processes A, B and C, threshold minimum 1.0\% and maximum $67.5 \%$ ).

\begin{tabular}{|c|c|c|c|c|c|c|c|}
\hline \multirow[b]{2}{*}{ Process } & \multirow[b]{2}{*}{ WPG (\%) } & \multicolumn{3}{|c|}{ UMSP-scanning profiles } & \multicolumn{3}{|c|}{ UV-Abs. spectra } \\
\hline & & $A_{280 \mathrm{~nm}}$ & StD & $\left(\right.$ pixel) ${ }^{b}$ & $\lambda(\mathrm{nm})$ & $A_{\max }$ & StD \\
\hline Untr. & 0 & 0.74 & 0.05 & 12733 & - & - & - \\
\hline A & 60 & 1.16 & 0.07 & 19752 & 278 & 1.24 & 0.07 \\
\hline B & 70 & 1.07 & 0.06 & 14426 & 256 & 1.21 & 0.07 \\
\hline C & 57 & 1.09 & 0.09 & 23103 & 278 & 1.20 & 0.06 \\
\hline
\end{tabular}

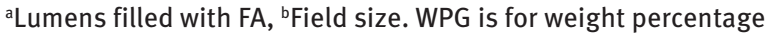
gain. StD is for standard deviation.

processing temperature and time and $\mathrm{pH}$ value of the solution) strongly affect the final product by the degree and type of chemical bonds (Lande et al. 2004a).

Compared to $\mathrm{W}_{\text {untr }}$, higher UV absorbances were also observed by UMSP on thermally modified wood $\left(160^{\circ} \mathrm{C}-\right.$ $180^{\circ} \mathrm{C}$ ) (Mahnert et al. 2013). Andersons et al. (2016) reported similar results at lower temperatures, but at $140^{\circ} \mathrm{C}$ for $1 \mathrm{~h}$ only a slight impact on the UV absorbance was seen. The furfurylation occurs below $140^{\circ} \mathrm{C}$ (Westin 2003). The chemical reactivity of the lignin is induced above a temperature of $80^{\circ} \mathrm{C}$ (Koch et al. 2003a) and real thermal changes of lignin are expected to begin at $150^{\circ} \mathrm{C}$ (Fengel and Przyklenk 1970). Ünver and Öktem (2013) showed that polymerized FA is characterized by a UV-A ${ }_{\max }$ at around $\lambda_{280 \mathrm{~nm}}$, i.e. which is also the case for untreated softwood lignins. Accordingly, the presented results concerning the absorbance increment at $280 \mathrm{~nm}$ can be unambiguously interpreted as a manifestation of the preferred deposition of (condensed) UV-active compounds at places of high lignin concentration in the cell wall. Most likely chemical bonds between FA and lignin were also produced, but of course, this assumption is not yet proved definitively.

\section{UV absorption spectra}

UV spectra with a spot size of $1 \mu \mathrm{m}^{2}$ in the wavelength range from 240 to $600 \mathrm{~nm}$ were recorded to study the spectral behavior of $\mathrm{W}_{\mathrm{FA}}$ on a cellular level. The spectral characteristics of the polymerized FA deposits in the cell lumen of $\mathrm{W}_{\mathrm{FA}}$ tissues are given in Figure 4. The UV spectra of the FA deposits from all three modification processes show approximately similar profiles. Common to all three modifications are (i) the high absorbance intensities, (ii) a distinct shoulder in the wavelength range between $\lambda_{340 \mathrm{~nm}}$ and $\lambda_{380 \mathrm{~nm}}$ and (iii) certain absorbance levels in the visible light range resulting from large chromophoric structures that were formed during the furfurylation processes. The absorption maxima of the FA deposits detected in $\mathrm{W}_{\mathrm{FA}, \mathrm{A}}$ and $\mathrm{W}_{\mathrm{FA}, \mathrm{C}}$ around $\lambda_{278 \mathrm{~nm}}$ are similar to the findings of Ünver and Öktem (2013). Comparable peaks around $\lambda_{270 \mathrm{~nm}}$ are also described by Gandini and Belgacem (1997), who studied the photopolymerization and photocrosslinking

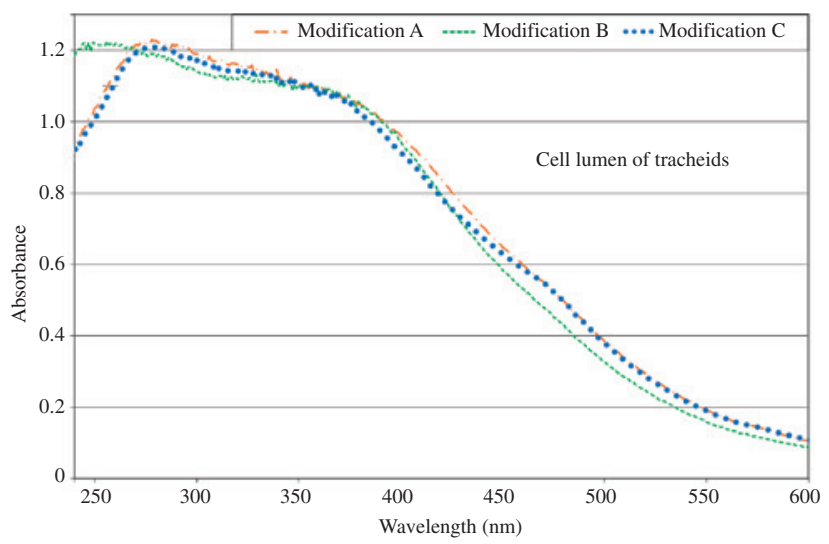

Figure 4: Representative UV absorbance spectra of polymerized FA deposited from all three modification processes in the cell lumens of radiata pine. 
of simple furans and $\mathrm{F}$. The $\mathrm{A}_{\max }$ of the deposits detected in $\mathrm{W}_{\mathrm{FA}, \mathrm{B}}$ are less pronounced and shifted hypsochromically (Nic et al. 2014) to $\lambda_{256 \mathrm{~nm}}$. This slight variation of the spectral behavior may have been caused by the individual process parameters of the furfurylation and are independent of sample loading (Table 1).

In Figure 5, representative lignin spectra of the individual cell wall layers of $\mathrm{W}_{\text {untr }}$ (black line) and the three furfurylated wood types are presented. The cell wall layers (S2, CML and CC) of $\mathrm{W}_{\text {untr }}$ show typical UV spectra of lignified softwood tracheids, with the characteristic $A_{\max }$ at
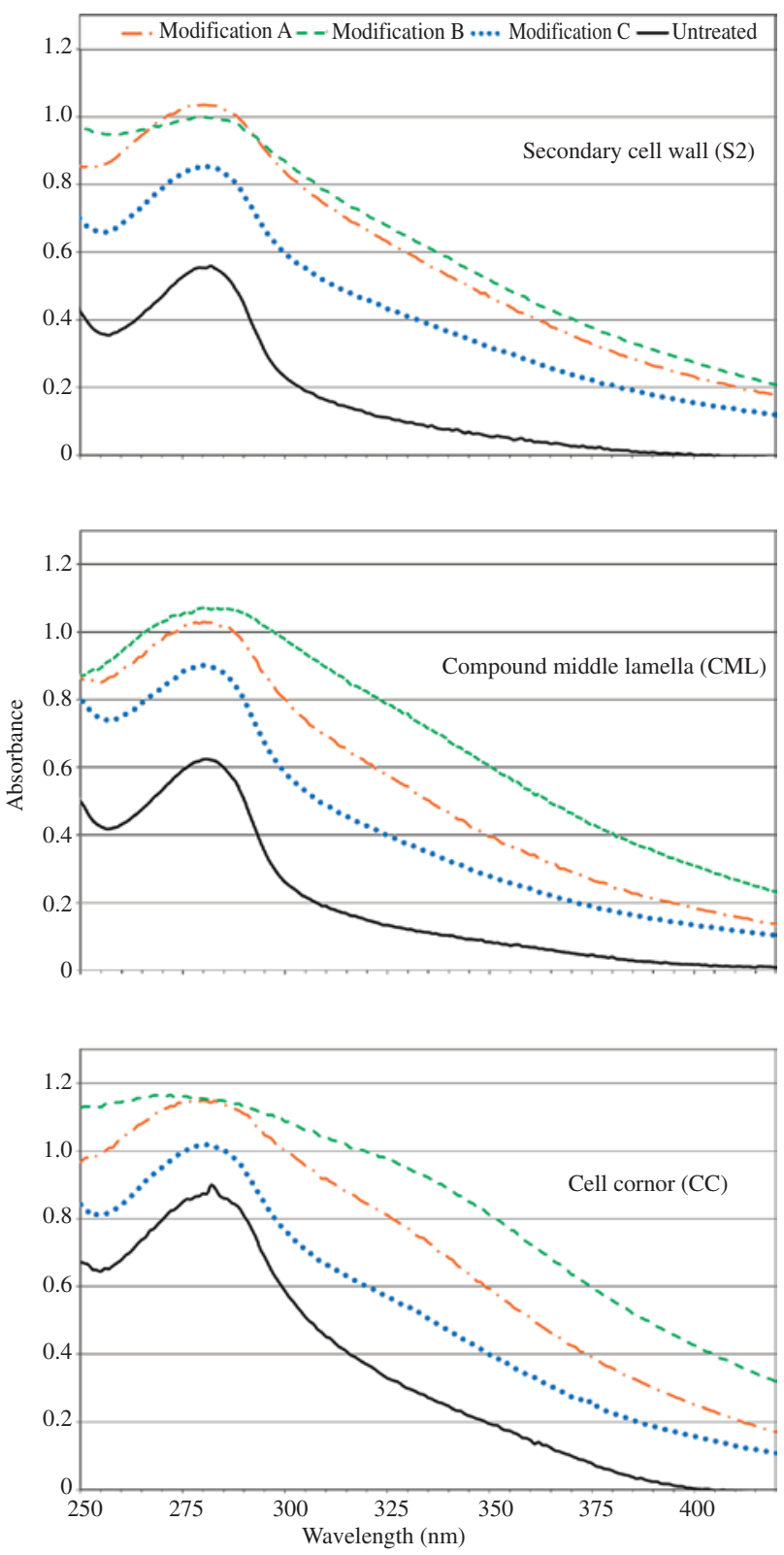

Figure 5: Representative UV absorbance spectra of the individual cell wall layers (S2, CML and CC) of untreated and furfurylated radiata pine (processes $\mathrm{A}, \mathrm{B}$ and $\mathrm{C}$ ). $\lambda_{280 \mathrm{~nm}}$ attributed to the strongly absorbing guaiacyl-type units (Musha and Goring 1975; Fujii et al. 1987). The different absorbance intensities at $\lambda_{280 \mathrm{~nm}}$ are strongly correlated to the lignin concentration, with the highest amount in the CC (Koch and Kleist 2001; Koch and Grünwald 2004). In this case, the absorbance in the $\mathrm{CC}$ of $\mathrm{W}_{\text {untr }}$ is 1.6 times higher than in the S2 (Table 2). The spectra of the modified cell wall layers show similar characteristics, with significantly higher absorbance values for the individual cell wall layers (Figure 5) as was already demonstrated by the UV scanning analyses.

The spectra of $\mathrm{W}_{\mathrm{FA}, \mathrm{C}}(57 \% \mathrm{WPG})$ appear close to the course of the $\mathrm{W}_{\text {untr, }}$, with generally higher absorbance intensities. The highest absorbances can be detected for the CC with $1.17\left(\mathrm{~A}_{272 \mathrm{~mm}}\right)$ and for the CML with 1.07 $\left(A_{280 \mathrm{~nm}}\right)$ for $\mathrm{W}_{\mathrm{FA}, \mathrm{B}}$, i.e. for specimens with the highest WPG (70\%) (Table 2). The spectra of these strongly modified cell wall layers display a bathochromic shift and shoulders with lower intensities around $320 \mathrm{~nm}$ (compared to $\left.\mathrm{W}_{\text {untr }}\right)$. This is probably due to the formation of conjugated double bonds. The higher degree of conjugation stabilizes $\pi-\pi^{\star}$ transitions resulting in bathochromic shifts (Goldschmid 1971). In comparison, the spectra of the CML and CC show a course more similar to the spectra of polymerized FA in the lumina $\left(\lambda_{300 \mathrm{~nm}}\right.$ and $\lambda_{370 \mathrm{~nm}}$, Figure 4), whereas the spectra of the S2 show only a shoulder with lower intensity. The strong increase from $0.56\left(\mathrm{~S} 2\right.$ in $\left.\mathrm{W}_{\text {untr }}, \mathrm{A}_{282 \mathrm{~nm}}\right)$ to $1.04\left(\mathrm{~S} 2\right.$ in $\left.\mathrm{W}_{\mathrm{FA}, \mathrm{A}}, \mathrm{A}_{278 \mathrm{~nm}}\right)$ and the shift of the bands of the $\mathrm{W}_{\mathrm{FA}}$ cell walls indicate a higher condensation of carbonyl groups as a possible reaction of FA with the guaiacyl units of softwood lignin (Lande et al. 2004c).

\section{Light microscopy and SEM}

The LM and SEM images give insight into the cellular deposition of polymerized FA in the tissues. Figure 6 presents the LM observations in the three anatomical directions (transverse, radial and tangential) of $\mathrm{W}_{\text {untr }}$ and $\mathrm{W}_{\mathrm{FA}}$ samples from the three process variants. The cross and radial sections include earlywood (EW) and latewood (LW). LW is easier to treat due to a larger amount of nonaspirated bordered pits compared to the EW (Phillips 1933; Liese and Bauch 1967; Zimmer et al. 2009). The sections in $\mathrm{W}_{\mathrm{FA}, \mathrm{A}}(60 \% \mathrm{WPG}$, Figure $6 \mathrm{~d})$ and $\mathrm{W}_{\mathrm{FA}, \mathrm{C}}(57 \%$ WPG, Figure 6j) show filled lumens in the LW. The transverse section of $\mathrm{W}_{\mathrm{FA}, \mathrm{B}}(70 \% \mathrm{WPG}$, Figure $6 \mathrm{~g}$ ) unexpectedly displays less filled lumens in the LW tracheids. As the treating solutions have the same pathways as in the living tree (Nicholas and Siau 1973), it was assumed that 
Table 2: Mean UV absorbances of the secondary cell wall (S2), compound middle lamella (CML) and cell corners (CC) of untreated and A-, B- and C-type modified radiata pine.

\begin{tabular}{|c|c|c|c|c|c|c|c|c|c|c|}
\hline \multirow[b]{2}{*}{ Process } & \multirow[b]{2}{*}{ WPG (\%) } & \multicolumn{3}{|r|}{ S2 } & \multicolumn{3}{|r|}{ CML } & \multicolumn{3}{|r|}{$\mathrm{CC}$} \\
\hline & & $\lambda(\mathrm{nm})$ & Abs. & $\Delta$ & $\lambda(\mathrm{nm})$ & Abs. & $\Delta$ & $\lambda(\mathrm{nm})$ & Abs. & $\Delta$ \\
\hline Untr. & 0 & 282 & 0.56 & & 281 & 0.62 & & 282 & 0.90 & \\
\hline A & 60 & 278 & 1.04 & 0.48 & 280 & 1.03 & 0.41 & 278 & 1.15 & 0.25 \\
\hline B & 70 & 280 & 1.00 & 0.44 & 280 & 1.07 & 0.45 & 272 & 1.17 & 0.27 \\
\hline C & 57 & 280 & 0.86 & 0.30 & 280 & 0.90 & 0.28 & 281 & 1.02 & 0.12 \\
\hline
\end{tabular}

The data are averages of 15-20 individual spectra. $\Delta$ is the absorbance difference between the untreated control and the FA-modified samples.
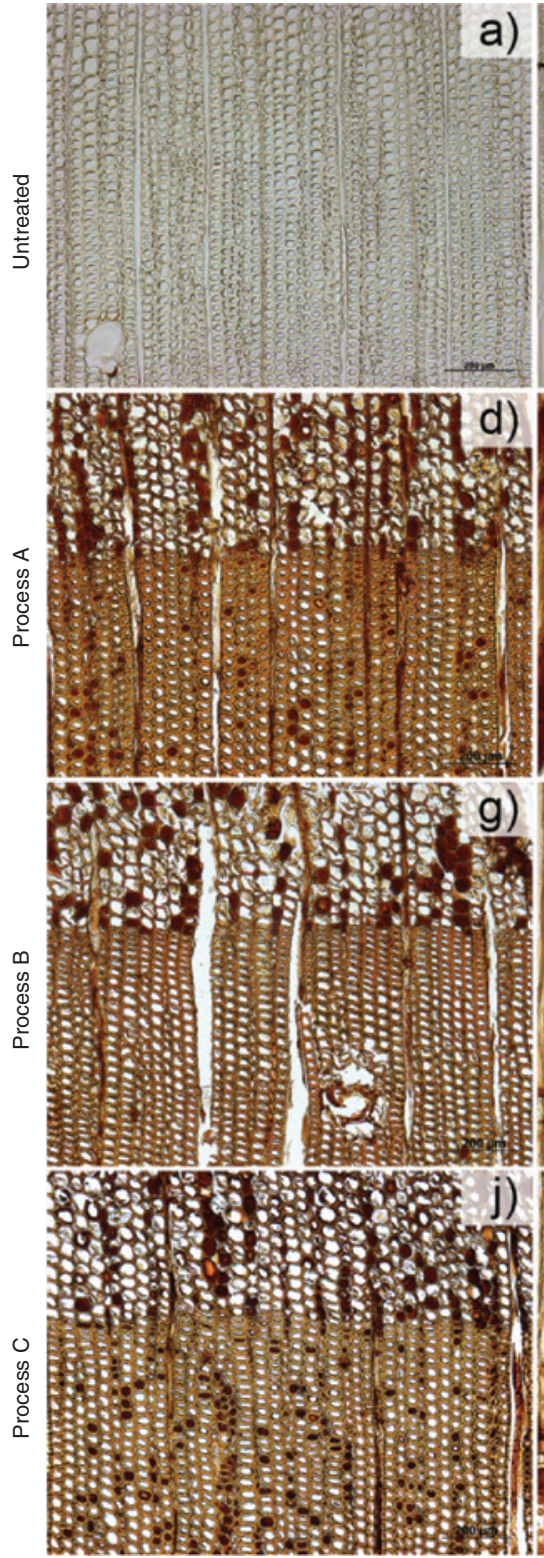

Figure 6: Light microscopic images of untreated $(6 a-c)$ and furfurylated radiata pine (processes $A, B$ and $C)$ in the three anatomical direc tions (transverse 6a, d, g, j; radial 6b, e, h, k; tangential 6c, f, g, l).

Compared to the untreated material, the furfurylated tissue appears darker with polymerized FA deposits in cell lumens. Filled ray tracheids are marked by arrows.
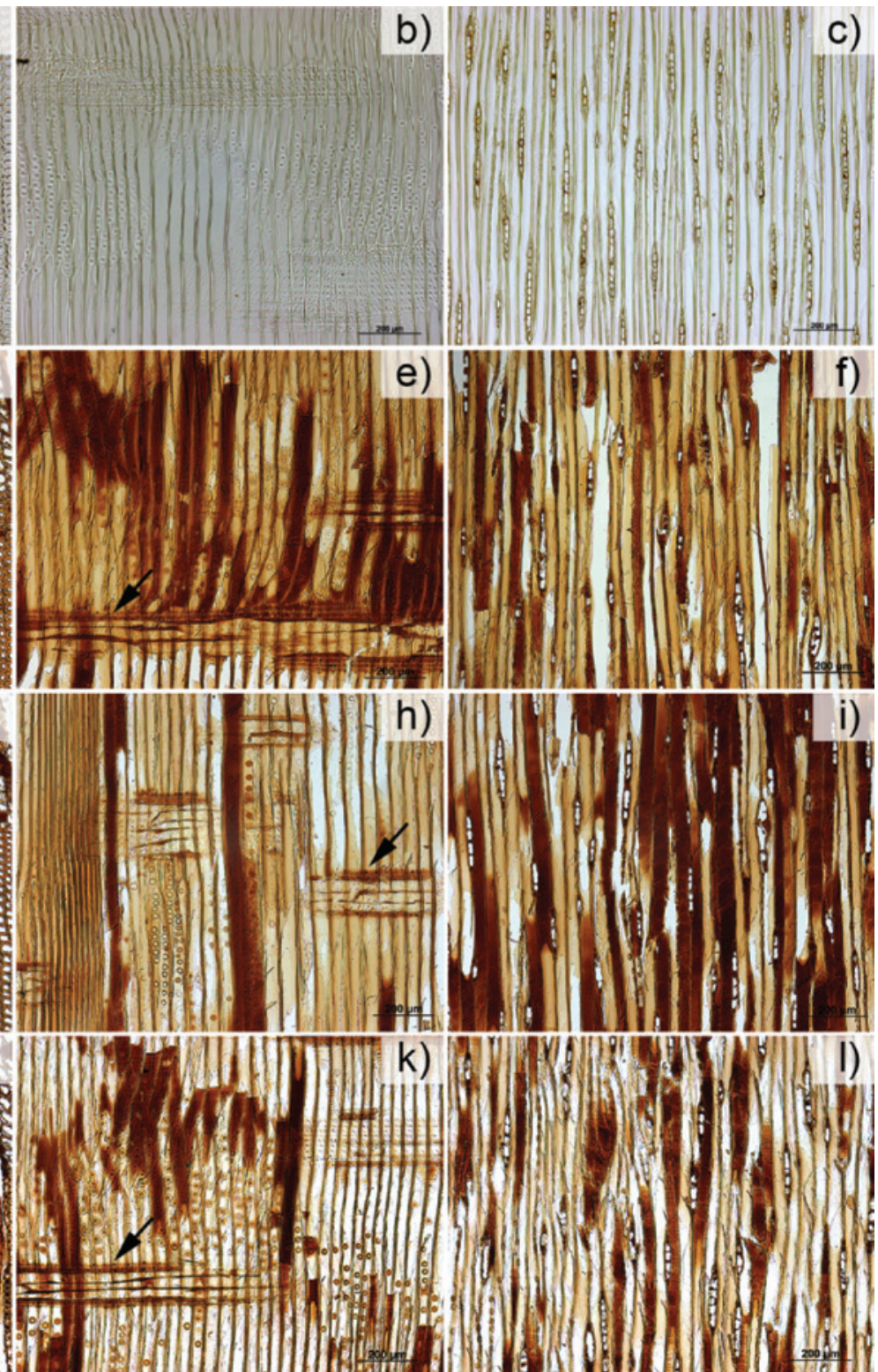

Bereitgestellt von | Technische Universität München 


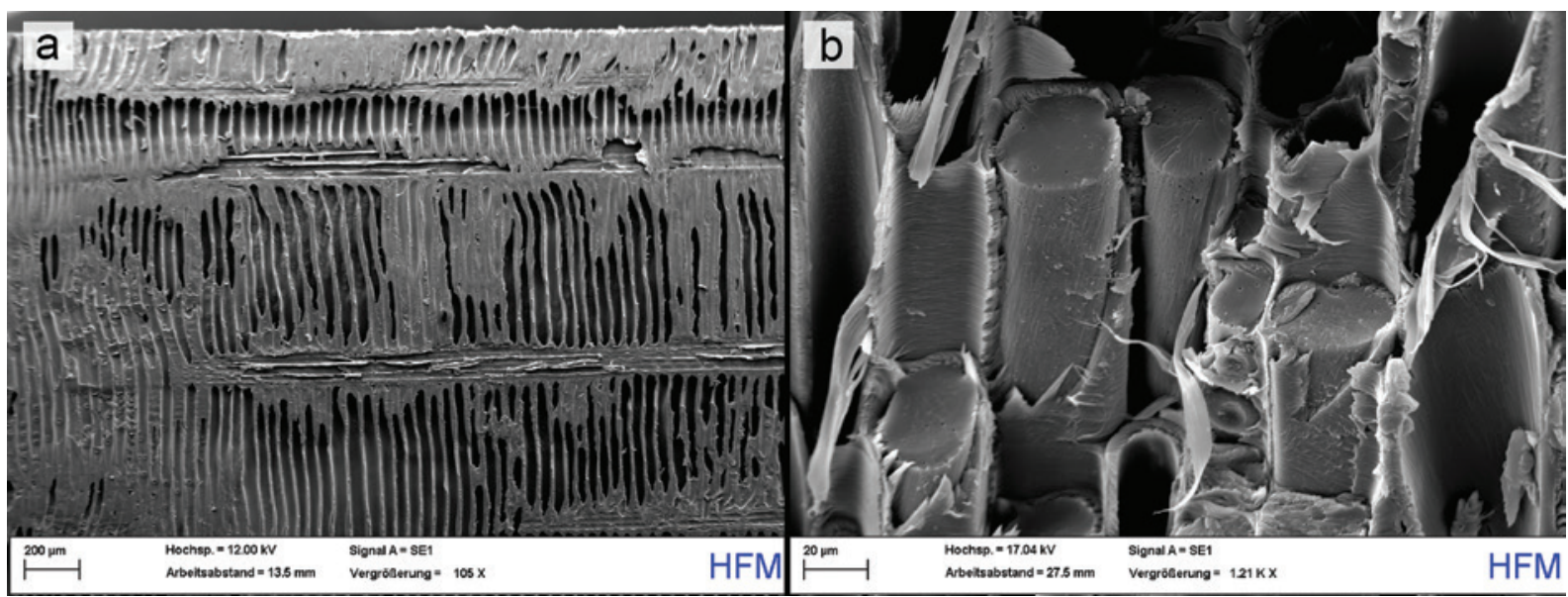

Figure 7: SEM images of furfurylated radiata pine.

The overview image shows the cellular distribution of polymerized FA deposits in the radial section (a). The polymerized FA is spatially displayed as a compact, lumen filling substance (b).

polymerized FA would be located in the easily accessible parenchyma cells of the wood rays. Radiata pine investigated by Wardrop and Davies (1961) showed an apparently selective penetration of ray parenchyma and less intensively penetrated ray tracheids. However, the radial and tangential sections of the $\mathrm{W}_{\mathrm{FA}}$ samples revealed that the FA was accessorily deposited in the ray tracheids (Figure 6e, h, k). One reason could be that the FA solution enters the ray tracheids predominantly via the connecting pits of the EW tracheids. The variability in filled cell lumens in the axial and radial directions supports the findings of Lande et al. (2010) or Zimmer et al. (2014) and are manifestations of varying permeability in Scots pine sapwood. This seems to also apply for radiata pine sapwood.

Aspirated tracheid bordered pits are assumed to function as physical barriers in case of impregnation (Stamm 1946; Zimmer et al. 2014). UMSP indicates a concentration decrement of polymerized FA from CML to S2. This can be explained by the early observation of Wardrop and Davies (1961) that aspirated bordered pits lead directly to the CML and serve as entrance openings during impregnation of the cell wall.

An uneven distribution and differently filled cell types can be seen. The permeability of $\mathrm{W}_{\text {untr }}$ may vary due to various physiological parameters in the living tree and also by the drying parameters (Booker 1990; Booker and Evans 1994; Zimmer et al. 2009, 2014; Lande et al. 2010). For successful wood protection system performance, a homogenous distribution of the treating solution in the wooden tissue is essential (Zimmer et al. 2012). Degradation studies reveal the importance of a consistent penetration and polymerization of FA during the production of
$\mathrm{W}_{\mathrm{FA}}$ (Venås 2008). Certainly, more systematic studies are needed in this context.

The SEM images (Figure 7) confirm the UMSP observations and provide more detailed information on the cellular distribution of polymerized FA deposits. The cell lumens of the ray parenchyma cells appear empty (Figure 7a), as already observed under LM. In Figure 7b, the polymerized FA is spatially displayed as a compact lumen-filling substance. These deposits are obviously attached to the tracheid walls.

\section{Conclusions}

UMSP is an appropriate method for topochemical studies of $\mathrm{W}_{\mathrm{FA}}$ subjected to various processes of modification. The measurements clearly show that the entire wood cell wall is modified, especially in the regions with the highest lignin concentration. The analyzed samples are characterized by strongly increased UV absorbances as a result of the formation of (condensed) aromatic compounds. This leads to the assumption that chemical bonds between FA and lignin may have been present. More specific knowledge of the nature of these bonds would probably be helpful in improving the biological resistance of furfurylated wood.

Acknowledgments: The authors extend their sincere thanks to the Research Council of Norway (RCN project 219294/O30, Wood-polymer composites for use in marine environments) for providing the test material. We also thank A. Vieler for sectioning, SEM preparations and analysis, and D. Paul and K. Brandt, Hamburg, for assistance in the UMSP analysis. 


\section{References}

Aguayo, M.G., Ferraz, A., Elissetche, J.P., Masarin, F., Mendonça, R.T. (2014) Lignin chemistry and topochemistry during kraft delignification of Eucalyptus globulus genotypes with contrasting pulpwood characteristics. Holzforschung 68:623-629.

Andersons, B., Noldt, G., Koch, G., Andersone, I., Meija-Feldmane, A., Biziks, V., Grinins, J. (2016) Scanning UV microspectrophotometry as a tool to study the changes of lignin in hydrothermally modified wood. Holzforschung 70:215-221.

Arantes, V., Qian, Y., Kelley, S.S., Milagres, A.M.F., Filley, T.R., Jellison, J., Goodell, B. (2009) Biomimetic oxidative treatment of spruce wood studied by pyrolysis-molecular beam mass spectrometry coupled with multivariate analysis and ${ }^{13} \mathrm{C}$-labeled tetramethylammonium hydroxide thermochemolysis: implications for fungal degradation of wood. J. Biol. Inorg. Chem. 14:1253-1263.

Arantes, V., Milagres, A.M., Filley, T.R., Goodell, B. (2011) Lignocellulosic polysaccharides and lignin degradation by wood decay fungi: the relevance of nonenzymatic Fenton-based reactions. J. Ind. Microbiol. Biotechnol. 38:541-555.

Bariska, M., Osusk, A., Bosshard, H.H. (1983) Änderung der mechanischen Eigenschaften von Holz nach Abbau durch Basidiomyceten. Holz Roh- Werkst. 41:241-245.

Bianchi, S., Koch, G., Janzon, R., Mayer, I., Saake, B., Pichelin, F. (2016) Hot water extraction of Norway spruce (Picea abies [Karst.]) bark: analyses of the influence of bark aging and process parameters on the extract composition. Holzforschung 70:619-631.

Booker, R.E. (1990) Changes in transverse wood permeability during the drying of Dacrydium cupressinum and Pinus radiata. New Zeal. J. For. Sci. 20:231-44.

Booker, R.E., Evans, J.M. (1994) The effect of drying schedule on the radial permeability of Pinus radiata D. Don. Holz Roh- Werkst. 52:150-156.

Bryne, L.E., Walinder, M.E.P. (2010) Ageing of modified wood. Part 1 : wetting properties of acetylated, furfurylated, and thermally modified wood. Holzforschung 64:295-304.

Danninger, E., Messner, K., Rohr, M. (1980) Abbauschema der Braun- und Weißfäulepilze auf heimischen Hölzern (Buche, Fichte). Holzforsch. Holzverw. 32:126-130.

Ehmcke, G., Pilgård, A., Koch, G., Richter, K. (2016) Improvement of a method for topochemical investigations of degraded furfurylated wood. Int. Wood Prod. J. 7:96-100.

Eriksson, K.E.L., Blanchette, R.A., Ander, P. Microbial and Enzymatic Degradation of Wood and Wood Components. Springer, Berlin, 1990.

Esteves, B., Nunes, L., Pereira, H. (2011) Properties of furfurylated wood (Pinus pinaster). Eur. J. Wood. Prod. 69:521-525.

Fackler, K., Stevanic, J.S., Ters, T., Hinterstoisser, B., Schwanninger, M., Salmén, L. (2010) Localisation and characterisation of incipient brown-rot decay within spruce wood cell walls using FT-IR imaging microscopy, Enzyme Microbial. Technol. 47:257-267.

Fengel, D., Przyklenk, M. (1970) Einfluß einer Wärmebehandlung auf das Lignin in Fichtenholz. Holz Roh- Werkst. 28:254-263.

Fergus, B.J., Procter, A.R., Scott, J.A.N., Goring, D.A.I. (1969) The distribution of lignin in spruce wood as determined by ultraviolet microscopy. Wood Sci. Technol. 3:117-138.
Fujii, T., Shimizu, K., Yamaguchi, A. (1987) Enzymatic saccharification on ultrathin sections and ultraviolet spectra of Japanese hardwoods and softwoods. Mokuzai Gakkaishi 33:400-407.

Fukazawa, K. (1992) Ultraviolet microscopy. In: Methods in Lignin Chemistry. Eds. Lin, S.Y., Dence, C.W., Springer-Verlag, Berlin. pp. 110-121.

Gandini, A., Belgacem, M.N. (1997) Furans in polymer chemistry. Prog. Polym. Sci. 22:1203-1379.

Gandini, A., Lacerda, T.M. (2015) From monomers to polymers from renewable resources: Recent advances. Prog. Polym. Sci. 48:1-39.

Gascon-Garrido, P., Oliver-Villanueva, J.V., Ibiza-Palacios, M.S., Militz, H., Mai, C., Adamopoulos, S. (2013) Resistance of wood modified with different technologies against Mediterranean termites (Reticulitermes spp.). Int. Biodeter. Biodegr. 82:13-16.

Goodell, B. (2003) Brown rot fungal degradation of wood: our evolving view. In: Wood deterioration and preservation: Advances in our changing world. Eds. Goodell, B., Nicholas, D., Schultz, T. American Chemical Society, Washington DC. pp. 97-118.

Goldschmid, O. (1971) Ultraviolet spectra. In: Lignins. Occurrence, Formation, Structure and Reactions. Eds. Sarkanen, K.V., Ludwig, C.H. Wiley-Interscience, New York. pp. 241-266.

Goldstein, I.S. (1955) The impregnation of wood to impart resistance to alkali and acid. Forest Prod. J. 5:265-267.

Goldstein, I.S. (1960) Impregnating solutions and methods. GB Patent 846,680.

Hill, C. Wood Modification: Chemical, Thermal and Other Processes. John Wiley \& Sons, Oxford, 2006.

Kielmann, B.C., Adamopoulos, S., Militz, H., Koch, G., Mai, C. (2013) Modification of three hardwoods with an N-methylol melamine compound and a metal-complex dye. Wood Sci. Technol. 48:123-136.

Kirk, T. (1975) Effects of the brown-rot fungus Lentzites trabea, on lignin in spruce wood, Holzforschung 29:99-107.

Koch, G., Grünwald, C. (2004) Application of UV microspectrophotometry for the topochemical detection of lignin and phenolic extractives in wood fibre cell walls. In: Wood Fibre Cell Walls: Methods to Study their Formation, Structure and Properties. Eds. Schmitt, U., Ander, P., Barnett, J.R., Emons, A.M.C., Jeronimidis, G., Saranpää, P., Tschegg, S. Swedish University of Agricultural Sciences, Uppsala. pp. 119-130.

Koch, G., Kleist, G. (2001) Application of scanning UV microspectrophotometry to localise lignins and phenolic extractives in plant cell walls. Holzforschung 55:563-567.

Koch, G., Schmitt, U. (2013) Topochemical and electron microscopic analyses on the lignification of individual cell wall layers during wood formation and secondary changes. In: Cellular Aspects of Wood Formation, Plant Cell Monographs 20. Ed. Fromm, J. Springer-Verlag, Berlin, Heidelberg. pp. 41-69.

Koch, G., Puls, J., Bauch, J. (2003a) Topochemical characterisation of phenolic cxtractives in discoloured beechwood (Fagus sylvatica L.). Holzforschung 57:339-545.

Koch, G., Rose, B., Patt, R., Kordsachia, O. (2003b) Topochemical Investigations on Delignification of Picea abies [L.] Karst. during alkaline sulfite (ASA) and bisulfite pulping by scanning UV microspectrophotometry. Holzforschung 57:611-618.

Kojima, Y., Kato, Y., Ishikura, Y., Yoon, S.-L., Ona, T. (2014) Photoyellowing of chemically modified chemithermomechanical pulps (CTMP) from Eucalyptus globulus under various atmospheres. Holzforschung 68:143-149. 
Lande, S., Eikenes, M., Westin, M. (2004a) Chemistry and ecotoxicology of furfurylated wood. Scand. J. Forest Res. 19:14-21.

Lande, S., Westin, M., Schneider, M. (2004b) Properties of furfurylated wood. Scand. J. Forest Res. 19:22-30.

Lande, S., Westin, M., Schneider, M.H. (2004c) Eco-efficient wood protection: Furfurylated wood as alternative to traditional wood preservation. Manage. Environ. Qual.: Int. J. 15:529-540.

Lande, S., Høibø, O., Larnøy, E. (2010) Variation in treatability of Scots pine (Pinus sylvestris) by the chemical modification agent furfuryl alcohol dissolved in water. Wood Sci. Technol. 44:105-118.

Li, W., Wang, H., Ren, D., Yu, Y.S., Yu, Y. (2015) Wood modification with furfuryl alcohol catalysed by a new composite acidic catalyst. Wood Sci. Technol. 49:845-856.

Liese, W., Bauch, J. (1967) On the closure of bordered pits in conifers. Wood Sci. Technol. 1:1-13.

Mahnert, K.-C., Adamopoulos, S., Koch, G., Militz, H. (2013) Topochemistry of heat-treated and $\mathrm{N}$-methylol melamine modified wood of Koto (Pterygota macrocarpa K. Schum.) and Limba (Terminalia superba Engl. et Diels). Holzforschung 67:137-146.

Martínez, A.T., Rencoret, J., Nieto, L., Jiménez-Barbero, J., Gutiérrez, A., Del Río, J.C. (2011) Selective lignin and polysaccharide removal in natural fungal decay of wood as evidenced by in situ structural analyses. Environ. Microbiol. 13:96-107.

Militz, H. (2002) Thermal treatment of wood: European prosesses and their background. IRG/WP 02-40241. In: Proceedings, International Research Group on Wood Protection, 12-17 May, Cardiff.

Moghaddam, M., Wålinder, M.E.P., Claesson, P.M., Swerin, A. (2016) Wettability and swelling of acetylated and furfurylated wood analyzed by multicycle Wilhelmy plate method. Holzforschung 70:69-77.

Musha, Y., Goring, D.A.I. (1975) Distribution of syringyl and guaicyl moieties in hardwoods as indicated by ultraviolet microscopy. Wood Sci. Technol. 9:45-58.

Nic, M., Jirat, J., Kosata, B. Compendium of Chemical Terminology (Gold Book). IUPAC, Durham, North Carolina. 2014.

Nicholas, D.D., Siau, J.F. (1973) Factors influencing the treatability of wood. In: Wood Deterioration and its Prevention by Preservative Treatment. Vol. 2. Ed. Nicholas, D.D. University Press, Syracuse. pp. 299-343.

Niemenmaa, O., Uusi-Rauva, A., Hatakka, A. (2008) Demethoxylation of [014CH3]-labelled lignin model compounds by the brown-rot fungi Gloeophyllum trabeum and Poria (Postia) placenta. Biodegradation 19:555-565.

Nordstierna, L., Lande, S., Westin, M., Karlsson, O., Furó, I. (2008) Towards novel wood-based materials: Chemical bonds between lignin-like model molecules and poly(furfuryl alcohol) studied by NMR. Holzforschung 62:709-713.

Pfriem, A., Dietrich, T., Buchelt, B. (2012) Furfuryl alcohol impregnation for improved plasticization and fixation during the densification of wood. Holzforschung 66:215-218.

Phillips, W.W.J. (1933) Movement of the pit membrane in coniferous woods, with special reference to preservative treatment. Forestry 7:109-120.

Pilgård, A., De Vetter, L., Van Acker, J., Westin, M. (2010a) Toxic hazard of leachates from furfurylated wood: Comparison between two different aquatic organisms. Environ. Toxicol. Chem. 29:1067-1071.
Pilgård, A., Treu, A., Van Zeeland, A.N.T., Gosselink, R.J.A., Westin, M. (2010b) Toxic hazard and chemical analysis of leachates from furfurylated wood. Environ. Toxicol. Chem. 29:1918-1924.

Rehbein, M., Koch, G. (2011) Topochemical investigation of early stages of lignin modification within individual cell wall layers of Scots pine (Pinus sylvestris L.) sapwood infected by the brown-rot fungus Antrodia vaillantii (DC.: Fr.) Ryv. Int. Biodeter. Biodegr. 65:913-920.

Ringman, R., Pilgård, A., Brischke, C., Richter, K. (2014) Mode of action of brown rot decay resistance in modified wood: a review. Holzforschung 68:239-246.

Rowell, R.M., Simonson, R., Hess, S., Placket, D.V., Cronshaw, D., Dunningham, E. (1994) Acetyl distribution in acetylated whole wood and reactivity of isolated wood cell wall components to acetic anhydride. Wood Fibre Sci. 26:11-18.

Saka, S., Whiting, K., Fukazawa, K., Goring, D.A.I. (1982) Comparative studies on lignin distribution by UV microscopy and bromination combined with EDXA. Wood Sci. Technol. 16:269-277.

Schneider, M.H. (1995) New cell wall and cell lumen wood polymer composites. Wood Sci. Technol. 29:121-127.

Schneider, M.H., Philips, J.G., Lande, S. (2000) Physical and mechanical properties of wood polymer composites. J. Forest Eng. 11:83-89.

Schultze-Dewitz, G. (1966) Relations between elasticity and static and impact bending strength of pinewood after exposure to basidiomycetes. Holz Roh- Werkst. 24:506-512.

Scott, J.A.N., Procter, A.R., Fergus B.J., Goring, D.A.I. (1969) The application of ultraviolet microscopy to the distribution of lignin in wood: description and validity of the technique. Wood Sci. Technol. 3:73-92.

Sejati, P.S., Imbert, A., Gérardin-Charbonnier, C., Dumarçay, S., Fredon, E., Masson, E., Nandika, D., Priadi, T., Gérardin, P. (2017) Tartaric acid catalyzed furfurylation of beech wood. Wood Sci. Technol. 51:379-394.

Sint, K.M., Adamopoulos, S., Koch, G., Hapla, F., Militz, H. (2012) Impregnation of Bombax ceiba and Bombax insigne wood with a N-methylol melamine compound. Wood Sci. Technol. 47:43-58.

Stamm, A.J. (1946) Passage of liquids, vapours and dissolved materials through softwoods. U.S. Forest Products Laboratory. Techical Bullentin 929.

Spurr, A.R. (1969) A low viscosity epoxy resin embedding medium for electron microscopy. J. Ultra. Mol. R. 26:31-43.

Stamm, A.J. (1977) Dimensional stabilization of wood with furfuryl alcohol resin. In: Wood Technology: Chemical Aspects. Ed. Goldstein, I. American Chemical Society, Washington DC. 43:141-149.

Stamm, A.J. Wood and Cellulose Science. The Ronald Press Company, New York, 1964.

Takabe, K. (2002) Cell walls of woody plants: Autoradiography and ultraviolet microscopy. In: Wood Formation in Trees. Ed. Chaffey, N. Taylor \& Francis, Singapore. pp. 159-177.

Thygesen, L.G., Barsberg, S., Venås, T.M. (2010) The fluorescence characteristics of furfurylated wood studied by fluorescence spectroscopy and confocal laser scanning microscopy. Wood Sci. Technol. 44:51-65.

Uppal, S.K., Gupta, R., Dhillon, R.S. (2008) Potential of sugarcane bagasse for production of furfural and its derivatives. Sugar Tech. 10:298-301. 
Ünver, H., Öktem, Z. (2013) Controlled cationic polymerization of furfuryl alcohol. Eur. Polym. J. 49:1023-1030.

van Eetvelde, G., De Geyter, S., Marchal, P., Stevens, M. (1998) Aquatic toxicity research of structural materials. IRG/WP 98-50114. In: Proceedings, International Research Group on Wood Protection, 19-19 June, Maastricht.

Venås, T.M. (2008) A study of mechanisms related to the fungal decay protection rendered by wood furfurylation. University of Copenhagen, Copenhagen.

Venås, T.M., Rinnan, Å. (2008) Determination of weight percent gain in solid wood modified with in situ cured furfuryl alcohol by near-infrared reflectance spectroscopy. Chemometr. Intell. Lab. 92:125-130.

VFF-Merkblatt H0.06-4 (2016). Holzarten für den Fensterbau - Teil 4: Modifizierte Hölzer.

Wardrop, A.B., Davies, G.W. (1961) Morphological factors relating to the penetration of liquids in wood. Holzforschung 15:129-141.

Westin, M. (2003) Furan polymer impregnated wood. Patent CA 2493512 C.
Winandy, J.E., Morrell, J.J. (1993) Relationship between incipient decay, strength, and chemical composition of Douglas-fir heartwood. Wood Fibre Sci. 25:278-288.

Yelle, D.J., Ralph, J., Lu, F., Hammel, K.E. (2008) Evidence for cleavage of lignin by a brown rot basidiomycete. Environ. Microbiol. 10:1844-1849.

Yelle, D.J., Wei, D., Ralph, J., Hammel, K.E. (2011) Multidimensional NMR analysis reveals truncated lignin structures in wood decayed by the brown rot basidiomycete Postia placenta. Environ. Microbiol. 13:1091-1100.

Zimmer, K.P., Larnøy, E., Koch, G. (2009) Wood properties affecting permeability of furfuryl alcohol in Scots pine sapwood. IRG/WP 09-40470. In: Proceedings, International Research Group on Wood Protection, 24-28 May, Beijing.

Zimmer, K.P., Larnøy, E., Høibø, O. (2012) Assessment of fluid flow paths and distribution in conifers. Wood Res. 57:1-14.

Zimmer, K.P., Høibø, O., Vestøl, G.I., Larnøy, E. (2014) Variation of treatability of Scots pine sapwood: A survey of 25 different northern European locations. Wood Sci. Technol. 48:435-447. 